A ballistic bomb calorimeter for the rapid determination of some nutritive values of foodstuffs. By H. C. Fox, D. S. Miller and P. R. PAyne .. .. .. ix

Pancreatic islet cells and blood-sugar regulation in pigs maintained on low-protein diets. By R. J. C. Stewart and C. R. C. Heard $\ldots \begin{array}{lllllll}\ldots & \ldots & \ldots & \ldots & \ldots & & \mathbf{x}\end{array}$

Protein metabolism in the rat with malaria (Plasmodium berghei). By I. S. DEMA, D. S. Miller and B. S. Platt $\quad \ldots \quad$.

Repeat individual weighed dietary surveys. By JEAN W. MARR, J. A. HEAdy and J. N. MORRIS

The rate of secretion of mixed saliva in the cow. By C. B. BAilley $\quad \ldots$
A simple graphing method for assessing child growth. By M. W. GRANT

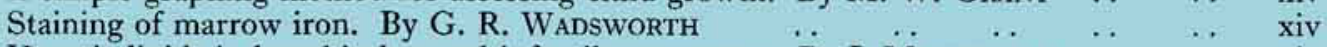

Hepatic lipids in kwashiorkor and infantile marasmus. By I. MACDONALD $\ldots$. . $\quad$ xiv

\begin{tabular}{|c|c|c|c|c|}
\hline Bailey, C. B. & .. & xiii & Hartles, R. L. & .. \\
\hline Barber, R. S. & .. & iii & Hawthorn, J. & .. \\
\hline Bradford, E. W. & .. & 75 & Heady, J. A. & .. \\
\hline Braude, R. .. & .. & iii & Heard, C. R. C. & .. \\
\hline Brothwell, D. R. & . & 59 & Heath, G. B. S. & . \\
\hline Brown, W. M. C. & . & 38 & Horsnell, A. M. & $\cdots$ \\
\hline Clark, F. Le G. & . & 1 & Jenkins, G. N. & . \\
\hline $\begin{array}{l}\text { Cope, Z. } \\
\text { Crossland, A. }\end{array}$ & $\begin{array}{l}\text {.. } \\
\text { ( }\end{array}$ & $\begin{array}{l}6 \\
\mathrm{i}\end{array}$ & & \\
\hline & & & Lenihan, J. M. A. & \\
\hline $\begin{array}{l}\text { Darling, A. I. } \\
\text { Dema, I. S. }\end{array}$ & $\because$ & $\begin{array}{r}70 \\
x i\end{array}$ & & \\
\hline Done, J. . . & .. & vi & Marr, J. W. & \\
\hline Fox, H. C. .. & . & ix & ell. $\mathrm{K}$ & \\
\hline & & $1 \mathrm{x}$ & Modi, V. V. & $\begin{array}{l}\cdots \\
\cdots\end{array}$ \\
\hline Godwin, K. O. & . & $\mathrm{v}$ & Morkam, F. E. & .. \\
\hline M. W. & & xiv & Morris, J. N. & .. \\
\hline Greaves, J. P. & & ii & Mullington, J. A. & .. \\
\hline
\end{tabular}

\title{
FORTHCOMING ISSUE
}

It is hoped to publish in the next issue of the Proceedings of The Nutrition Society reports of symposia on Rumen Function (7 March 1959) and Obesity (4 April 1959) and abstracts of communications to be presented at the Open Scientific Meetings on 7 February and 29 May 1959. 


\title{
CONTENTS OF VOLUME 18, No. 1, 1959
}

\author{
(All rights reserved)
}

\author{
SYMPOSIUM PROCEEDINGS \\ One Hundred and Eighteenth Scientific Meeting \\ THE HUMAN FACTOR IN GROUP FEEDING
}

PAGE

Alexis Soyer (1809-1858) - an historical note on his contributions in applied nutrition.

By F. Le Gros Clark $\quad \begin{array}{llllllllllll} & \ldots & & \ldots & \ldots & \ldots & \ldots & \ldots & \ldots & \ldots\end{array}$

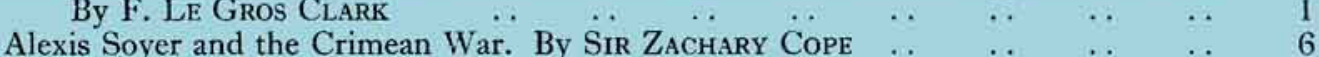

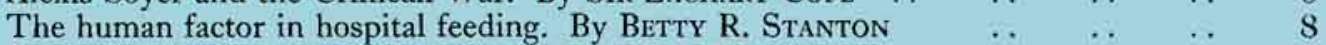

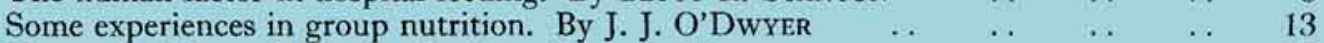

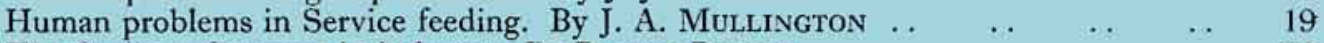

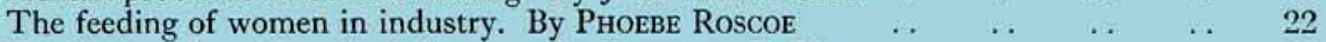

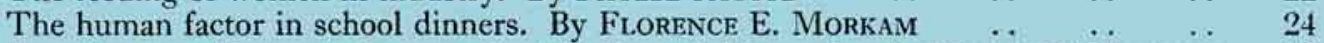

Appetites in retirement: the organized feeding of old people. By Denise W. Newman 28

\section{One Hundred and Nineteenth Scientific Meeting}

\section{NUTRITIONAL HAZARDS CAUSED BY RADIOACTIVE CONTAMINATION OF FOODS}

The scientific basis of the radiation hazard. By J. M. A. LeniHAN . 0 .

Some reflections on the possible hazards to man of low doses of radiations. By W. M.

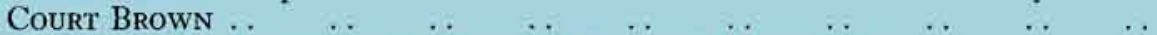

The occurrence of radiostrontium in foodstuffs. By J. HAWTHORN . . $\quad \ldots \quad \ldots$

Nutritional hazards caused by radioactive contamination of foods. By G. B. S. HEatH

\section{One Hundred and Twentieth Scientific Meeting \\ NUTRITION AND TEETH}

Nutrition and the teeth. By F. C. Wilkinson $\begin{array}{lllllllllll}\text {. } & \ldots & \ldots & \ldots & \ldots & \ldots & 54\end{array}$

$\begin{array}{lllllll}\text { Teeth in earlier human populations. By D. R. BROTHWELL } & \ldots & \ldots & \ldots & \ldots & & \\ 99\end{array}$

The histochemistry of human tooth development. By A. R. Ten CaTe $\quad \ldots \quad$. $\quad 65$

The structure of the human tooth. By A. I. DARLING $\quad \begin{array}{llllllll} & \ldots & \ldots & & \ldots & \ldots & 70\end{array}$

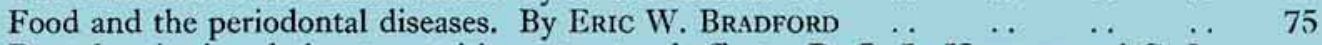

Dental caries in relation to nutrition: structural effects. By R. L. HARTLES and G. L.

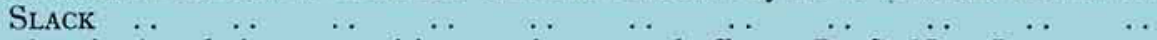

Dental caries in relation to nutrition: environmental effects. By G. NeIL Jenkrns ..

A combined attack upon a common problem. By A. M. Horsnell and Ella ScotT

\section{ABSTRACTS OF COMMUNICATIONS \\ One Hundred and Twenty-first Scientific Meeting}

Species differences in the occurrence of xanthine oxidase in milk. By V. V. Mod, E. C. OWEN and R. Proudfoot $\quad \ldots \quad$.

The effect of tungstate on xanthine oxidase in goat's milk. By A. Crossland, E. C. OWEN and R. Proudfoot

Growth and reproduction of mice fed on wheat grown under different systems of soil management. By J. P. Greaves and Patricia P. Scott $\ldots \quad \ldots \quad \ldots \ldots$

Leaf protein in rations of growing pigs. By R. S. BARBER, R. Braude and K. G. MITCHELL

The effect of a low-protein diet on the urinary excretion of urea. By G. R. WADSWORTH and T. S. LEE ..

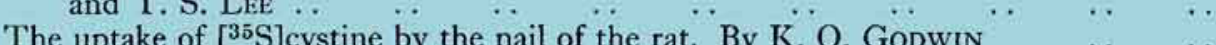

The equilibration of water and of serum albumin labelled with tritium, in the body fluids of pigs maintained on normal, low-protein and low-protein plus carbohydrate diets. By P. R. PAYNe and J. Done

The net dietary-protein value (N.D-p.v.) of mixtures of foods-its definition, determination and application. By B. S. PLATT and D. S. Miller .. .. .

The estimation of net dietary-protein value (N.D-p.v.) of meals and diets from the total sulphur content. By D. S. Miller and D. J. NAISMith $\quad \ldots \quad \ldots \quad \ldots$

[Continued on p. iii of wrapper] 